\title{
POLITICAL "IDEALISTIC" LEADERSHIP AND THE RULE OF LAW
}

\author{
Larisa Vasileska ${ }^{1}$
}

DOI: https://doi.org/10.31410/LIMEN.2019.141

\begin{abstract}
One of the most difficult concepts to define and give universal definition certainly is the concept of "leadership," because it is applicable in every aspect of our life. The orthodox meaning of leadership is "for individual within a group to lead and others to follow." However, here it addresses the dilemma of where, exactly the quality of the "leader" or the "leadership" resides. Is it morality important for leadership? What about the concept of "ethical consciousness" of a leader? Almost every politician we hear today regularly extols the rule of law. However, what does the rule of law actually mean? We need leaders who better understand the rule of law. This paper will try to find answers to very thorny question: If we define leadership as value-based virtue, which values matter most? In addition, how do we deal with the most sensitive decisions made by governments, which are currently incompatible with the definitions of the rule of law and international law.
\end{abstract}

Keywords: Political leadership, Idealistic leadership, Morality, Ethics, Rule of law.

\section{INTRODUCTION}

$\mathrm{T}$ he great Nelson Mandela said that, "A leader is like a shepherd. He stays behind the flock, letting the most nimble go out ahead, whereupon the others follow, not realizing that all along that they are being directed from behind."

Leadership is one of the most widely studied topics today. Authors are constantly publishing articles and books attempting to tackle the numerous variables associated with "successful leadership.”(Waggoner, 2010)

In the existing literature, leadership is defined in so many different ways that it is hard to come up with a single working definition. With the changing times, the definition of leadership is also changing. In a democratic society a leader is no more seen as a powerful or an influential person telling people what to do and what not to. But, in a country where there is no rule of law, it seems that the leaders, and in this case political leaders, are still influential and sometimes it seems that they have magical "powers" with "idealistic" believes to "hypnotize" people and make them believe in the things that they are saying, because those things are the "best" for them as citizens and for the whole country.

The purpose of this paper is to shed light on the construct of ethical and idealistic political leadership by reviewing the relevant literature. The aim of the paper include providing definitions of leadership, ethical values and describing ethical political leader's personality.

Leaders in my opinion should operate outside the boundaries of organizationally defined procedures. As the great Sun Tzu in his The Art of War wrote: „Don't follow where the pathway goes, lead instead where there is no path and leave a trail." Leadership should involve risk and

University „St. Kliment Ohridski” - Bitola, FTU - Ohrid, Kej Makedonija br.95, Republic of North Macedonia 
uncertainty, and the reality of leadership always requires that someone should accept the risk as a part of their job, when acting outside the prescribed procedures. But one should always act according to the rule of law and never forget the moral and ethical values.

It is said that "part of what makes humans unique is our freedom to determine how we'll act." Thomas Aquinas, Italian philosopher from 1265-1274 in his work "Summa theologiae" wrote: "that our conscience emerged from synderesis which means the 'spark of conscience'. He literally meant that the human mind has the ability to understand the world in moral terms. Conscience was the process by which a person brought the principles of synderesis into a practical situation through our own decisions. We have the ability to make practical decision in light of ethical values and principles" (The Ethical Centre, 2017)

On the other hand, in Aristotelian ethics, Aristotle (384-322 B.C.E.) is using the word "phronesis", which is an ancient Greek word for a type of wisdom or intelligence, type of wisdom relevant to a good judgment. Or literal meaning "the goodness of practical reason", or the ability to evaluate the situation clearly, so we would know how to act virtuously under the given circumstances. Science says that our conscience is formed or shaped by experience or by education and through that we are aware of the facts, evidence and circumstances which enables us to act accordingly. "Seeing conscience in this way is important because it teaches us that ethics is not innate. By continuously working to understand our surroundings, we strengthen our moral muscle." (The Ethical Centre, 2017)

Aristotle in his best-known work on ethics, "Nichomachean Ethics" is emphasizing the role of habit in conduct. According to Aristotle, it is commonly thought that virtues, "are habits and that the good life is a life of mindless routine." Aristotle also uses the word "hexis" to indicate the moral virtue.

Most of the political debates nowadays, are linked to conscientious objection, to the objections on moral or religious grounds or objections for reasons of conscience complying with a particular requirements. It seems that all of us would like to have an answer to the many questions that we constantly ask ourselves, for instance: "Should pro-life doctors be required to perform abortions or refer patients to doctors who will? Must priests break the confessional seal and report sex offenders who confess to them?" Most of the Western nations, believed in the idea that a person should never be forced to do something that is against their deeply held values and principle, or simply described as the "primacy of conscience". (The Ethical Centre, 2017)

Perhaps the subtlest, and therefore most elusive, dimension of leadership concerns values. For some, the word „leadership" is a totally value-neutral term. Anyone who influences others is a leader regardless of whether the impact is positive or negative. As educator Parker Palmer has noted, ,a leader is someone with the power to project shadow or light onto the world around him. The result can be a world as light-filled as heaven or as shadowy as hell". (Palmer, 2000)

A leader with an understanding of ethics, a history of ethical decision-making and the ability to develop and execute plans of action shows stability, empathy, integrity and resolve. All of these traits shown in a leader's track record will infuse a greater sense of trust within followers.

Jessica Waggoner in her thesis “„Ethics and Leadership: How Personal Ethics Produce Effective Leaders" states that: "Without good ethics it is extremely difficult for a leader to develop 
integrity, authenticity, an identity or other traits that produce effective leadership. Without these characteristics it is impossible for a leader to develop trust. Without the glue of leadership it is very unlikely a leader will be effective. As you can see, good personal ethics are the backbone of effective leadership. "(Waggoner, 2010)

Piter Van Lockem (2017) in his paper "Legislation against the rule of law - an Introduction" writes that the "rule of law seems an important as well as a vulnerable rule. The importance depends on whether one prescribes a thick or thin definition of the rule of law. Even in a thin concept, according to which the rule of law implies foremost that the actions of government officials and those of citizens are bound by the law, the rule of law is of great significance."

The most important requirement made by the international donor-institution and European Union, for the countries that want to join the Union is implementing the rule of law. This requirement from the European foreign policy makes the rule of law an export product and has a negative implications for the countries that need to implement the rule of law and leaves hardly any room for democratic participation in the rule making. "This policy not only undermines democracy in the receiving countries, but undermines the development of the rule of law as well, because of not having a legislation process by which governments and citizens bind each other in a mutual and reciprocal context." (van Lochem, 2017).

In failed states it is even common to ignore the rule of law. However, unfortunately, it seems that nowadays, there is a growing tendency political leaders of the countries that are considered to be on the top of the rule of law list and countries that are governed by the rule of law, to make questionable statements about the rule of law. From their statements we can conclude that they actually don't understand the true meaning of the rule of law. Here are quote parts of actual statements from the US political leaders indicating: "'disdain for the rule of law', 'assaulting the rule of law' or even 'mobilizing for war against the rule of law"'. Political leaders from US are not the only ones giving contradictory statements. Media in the European countries, the ones that have so many requirement for others on the concept of the rule of law, has recorded statements by the EU political leaders "prepared to limit or even act against the rule of law." (van Lochem, 2017).

One of the cases that is argued every day in the media is the decision of the Macedonian government in changing the name of the country. A referendum was held in the Republic of Macedonia on 30 September 2018, with voters asked whether they support EU and NATO membership by accepting the agreement struck between the Republic of Macedonia and Greece in June 2018. A referendum to change the name of Macedonia failed to secure the 50 percent turnout required to make the vote valid, with registered voter turnout of $36.8 \%$.

The Universal Declaration of Human Rights recognized that "everyone has the right to take part in the government of their country", and that "the will of the people shall be the basis of the authority of government." The citizens of Macedonia did not give authority to the Macedonian Government to change their country's name and identity. Notwithstanding the will of the people expressed in the failed referendum still, the international community and our government are pushing for implementation of the Prespa Agreement. So where is the rule of law in all of this? Where are the moral and ethical values that governments from European Union are pushing? According to European Parliament website, the European Union's fundamental values are respect for human dignity and human rights, freedom, democracy, equality and the rule of law. 
These values unite all the member states - no country that does not recognize these values can belong to the Union.

The name of Macedonia was changed with a promise of a better future, and without regard to the enormous expense to the nation of creating a new, semi-sovereign country, with a new name and a new internal and international legal identity.

But, maybe the world leaders that are pushing the implementation of the Prespa Agreement have forgotten the legal maxim "Lex iniusta non est lex" originating with St. Augustine and used by St. Tomas Aquinas, "an unjust law is no law at all".

\section{POLITICAL IDEALISTIC LEADERSHIP VERSUS PRAGMATIC POLITICAL LEADERSHIP}

According to vocabulary.com. "An idealist is someone who envisions an ideal world rather than the real one. Some people consider idealists to be naive, impractical, and out of touch with reality. Idealists think that striving for perfection makes the world a better place. In the article in Forbes woman, by Susan Gunelius, where she argues which leader is better -- a pragmatic, realistic leader or an idealistic, visionary leader, she gives very interesting definition. She writes that the idealistic leaders are actually visionary thinkers. "They focus on the big ideas and end results with less concern with the steps to get there. Therefore, they can be accused of looking through rose-colored glasses when, in fact, they simply "see" the end goal and truly believe there is a way to get there." (Gunelius, 2010)

Antonym of idealist is pragmatist. According to vocabulary.com "a pragmatist is someone who is practical and focused on reaching a goal. A pragmatist usually has a straightforward, matterof-fact approach and doesn't let emotion distract him. A pragmatist can also ignore her own ideals to get the job done, so in this way it can have a slightly negative meaning. The word is often used in reference to politicians to mean that they are either sensible or willing to cut corners for their cause." (vocabulary.com) So it seems that most of the political leaders in the world politics are not idealist, but pragmatist leaders and they only focus on the processes behind any task, initiative, or goal with a main priority just to figure out how the team is going to get things done. Without any concern of the rule of law, ethics or moral values.

As we emphasized before, being ethical is about playing fair, thinking of others and thinking about consequences of one's actions. Ethical leaders think about long-term consequences, drawback and benefits of their decisions. For the sake of being true to their own values and beliefs, they are prepared to compete in a difference battle, (Mihelic et al, 2010) in our case on the political arena, where the imperative is: Do what is right.

The criteria relevant for judging ethical behavior of a leader include individual values, conscious intentions, freedom of choice, stage of moral development, types of influence used, and use of ethical as well as unethical behavior (G. Yukl, 2006).

Up until now, we agreed on defining leadership as value-based virtue. Professor Donald G. Zauderer compares ethical versus unethical leaders and states some of the characteristic behaviors/ values of ethical political leader and unethical political leader. 


\begin{tabular}{|l|l|}
\hline Characteristic behavior of the Ethical Leader & Characteristic behavior of the Unethical Leader \\
\hline $\begin{array}{l}\text { "humble person, maintains concern for the greater } \\
\text { good, is honest and straightforward, fulfill commit- } \\
\text { ments, shows respect for each individual, encourag- } \\
\text { es and develops others, shows courage to stand up } \\
\text { for what is right." }\end{array}$ & $\begin{array}{l}\text { "arrogant and self-serving, excessively promotes } \\
\text { ments, deals unfairly, shifts blame to others, dimin- } \\
\text { ishes others' dignity, withholds help and support, } \\
\text { lacks courage to confront unjust acts." }\end{array}$ \\
\hline
\end{tabular}

Source: Based on Donald G. Zauderer in his paper

“Integrity: An Essential Executive Quality," Business Forum, (Fall 92), pp. 12-16

Values are general principles that guide action. Values are not actions, they are codes which underlie the sanctions or punishments for some choices of behavior and rewards for other. Throughout history values have sparkled interest of many researchers in various sciences. (Mihelic et al, 2010). According to Dolan et al (2006), ethical moral values refer to forms of conduct that one has to live by in order to reach desired outcomes in the form of final values.

Stephen Covey is an author on leadership that popularizes the notion that leadership inherently involves core values, or principles, that inform the leader's actions. According to him, the most effective leaders are, first models of what he calls principle-centered leadership. „They have come to realize that we're all subject to natural laws or governing principles, which operate regardless of our awareness of them or our obedience to them. Our effectiveness is predicated upon alignment with these inviolable principles -- natural laws in the human dimension that are just as real, just as unchanging, as laws such as gravity are in the physical dimension. These principles are woven into the fabric of every civilized society and constitute the roots of every organization that has endured." (Convey, 1996)

\section{CONCLUSION}

\section{The art of leading others come from the art of leading oneself} Philippe Daudi

The widespread fascination with leadership may be because of the impact that leadership has on everyone's life. Leadership is one of the most discussed topics today. Authors are constantly writing articles trying to find the perfect answer to what is a "successful political leadership."

The degree of ethics in leadership is determined by relevant argumentation and debates. Ethics of politics focuses on the relationship between politics and morality. The politics itself cannot be exempt from morality, moral standards and principles. We should all agree with the opinion that ethics of politics has to focus both on ethics of political virtues (justice, wisdom, conscience, law, responsibility, and obligation) and also on ethics of political institutions (moral aspects of progress, international politics ethics).

We must conclude that, good political leadership "must include strong morals and be effective at the same time because a leader's role is to utilize tension and conflict within people's value systems and play the role of raising people's consciousness". In conclusion, if political leaders understand the importance of ethics and ethical behavior that can positively affect leadership and when the above mentioned virtues are a priority for leaders, it will result or produce ethical and effective leadership. 


\section{REFERENCES}

Aristotle, Joe Sachs (trans.). (2002). Nicomachean Ethics, Focus Philosophical Library, Pullins Press

Burns, J. M. (1978). Leadership. New York: Free Press.

Covey, Stephen R. (1996). „Three Roles of the Leader in the New Paradigm” in Hesselbein, F., Goldsmith, M., and Beckhard, R. The Leader of the Future. New York: Drucker Foundation, pg. 151

Dolan, S. L., Garcia, S., \& Richley, B. (2006). Managing by values; A corporate guide to living, being alive and making a living in the 21st century. New York: Palgrave Macmillian.

Gerzon., Mark. (2003). Leaders and Leadership, Retrieved from https://www.beyondintractability.org/essay/leaders\#narrow-body

Gunelius, Susan (2010). Are You a Pragmatic or Idealist Leader? Forbes Woman, Retrieved from https://www.forbes.com/sites/work-in-progress/2010/04/15/are-you-a-pragmatic-oridealist-leader/\#41420fec3e67

Mihelič, Katarina Katja, Lipičnik, Bogdan \& Tekavčič, Metka (2010). Ethical Leadership, International Journal of Management \& Information Systems - Fourth Quarter 2010, Volume 14, Number 5

Palmer, Parker. (2000). Let Your Life Speak. San Francisco: Jossey Bass

The Ethics Center: Ethics Explainer: Conscience, Retrieved from https://ethics.org.au/ethics-explainer-conscience/

Van Lochem, Peter (2017) Legislation against the rule of law - an introduction, The Theory and Practice of Legislation, 5:2, 95-100, DOI: 10.1080/20508840.2017.1387729

Waggoner, Jessica. (2010). „Ethics and Leadership: How Personal Ethics Produce Effective Leaders", CMC Senior Theses. Paper 26. http://scholarship.claremont.edu/cmc_theses/26

Yukl, G. (2006). Leadership in organizations, 6th edition. New Jersey: Pearson Prentice Hall Upper Saddle River, NJ.

Zauderer, Donald G. (1992).Integrity: An essential executive quality, Business Forum; Fall 92, Vol. 17 Issue 4, p.12 